\title{
PENILAIAN TERHADAP KESESUAIAN ANTARA PENETAPAN BEA KELUAR ATAS EKSPOR MINERAL DENGAN ASAS KEPASTIAN HUKUM DAN ASAS EKONOMIS*
}

\author{
Paripurna P Sugarda ${ }^{* * *}$ dan Irine Handika ${ }^{* * *}$ \\ Departemen Hukum Dagang, Fakultas Hukum Universitas Gadjah Mada, Yogyakarta \\ Departemen Hukum Pajak, Fakultas Hukum Universitas Gadjah Mada, Yogyakarta \\ Jalan Sosio Yustisia Nomor 1 Bulaksumur, Sleman DI Yogyakarta 55281
}

\begin{abstract}
The regulation of the mineral mining sector underwent significant changes as a result of the enactment of the government's policy to increase export duties on mineral exports. This paper examines wether the new regulation is in conformity with the principle of legal certainty and the principle of economy, as well as trying to find the ideal scheme in determining the Mineral Export Levy. This research concludes that there is conformity between new regulation and legal certainty, but there is unconformity with the principle of economy. The ideal scheme is to include consideration of the realitation of justice.
\end{abstract}

Keywords: export tariff, mineral export, legal certainty, economic principles.

\section{Intisari}

Regulasi sektor usaha pertambangan mineral mengalami perubahan signifikan sebagai akibat ditetapkannya kebijakan pemerintah memungut bea keluar terhadap ekspor mineral. Tulisan ini berusaha mengkaji regulasi tersebut dalam kesesuaiannya dengan asas kepastian hukum dan asas ekonomi, serta mencoba mencari skema ideal dalam menentukan Bea Keluar Ekspor Mineral. Hasil penelitian ini menyimpulkan bahwa Penetapan BK Mineral telah sesuai dengan asas kepastian hukum namun belum sesuai dengan asas ekonomis. Skema yang ideal di dalam penatapan BK Ekspor Mineral adalah dengan memasukkan pertimbangan realisasi keadilan

Kata Kunci: tarif ekspor, ekspor mineral, kepastian hukum, kepastian ekonomi.

\section{Pokok Muatan}

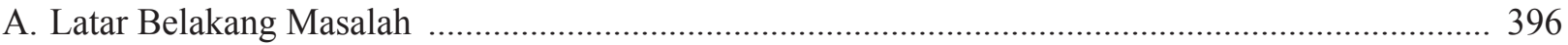

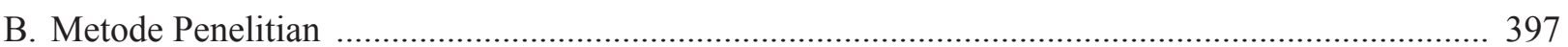

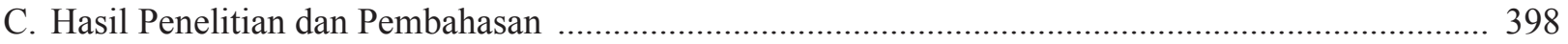

1. Kesesuaian Penetapan BK Ekspor Mineral dengan Asas Kepastian Hukum ............................. 398

2. Kesesuaian Penetapan BK Ekspor Mineral dengan Asas Ekonomis .......................................... 406

3. Skema Penetapan BK Ekspor Mineral yang Ideal........................................................................... 408

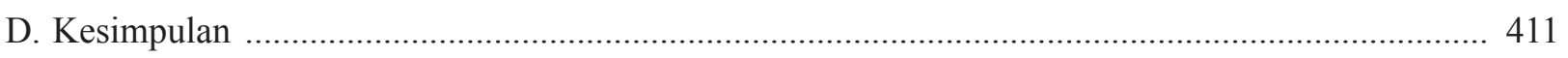

Hibah Penelitian dari Unit Penelitian dan Pengabdian kepada Masyarakat Fakultas Hukum UGM Tahun 2014.

** Alamat Korespondensi: paripurna@mail.ugm.ac.id.

**** Alamat Korespondensi: irenehandika@ugm.ac.id. 


\section{A. Latar Belakang Masalah}

Sektor usaha pertambangan mineral mengalami perubahan signifikan akibat ditetapkannya kebijakan pemerintah untuk memungut bea keluar terhadap ekspor mineral (selanjutnya disebut BK Mineral). Perubahan tersebut dimulai dengan dikeluarkannya PMK No. 75/PMK.011/2012 sebagaimana diubah oleh PMK No. 128/PMK.011/2013 tentang Penetapan Barang Ekspor yang Dikenakan Bea Keluar dan Tarif Bea Keluar, yang menetapkan pemungutan BK Mineral terhadap barang ekspor berupa bijih mineral (raw material atau ore) dengan tarif sepadan sebesar $20 \%$ dari Harga Ekspor. Pengaturan itu diubah melalui PMK No. 6/PMK.011/2014 (selanjutnya disebut PMK 6/2014), yang terakhir diubah oleh PMK No. 153/PMK.011/2014 (selanjutnya disebut PMK 153/2014). ${ }^{1}$ PMK 6/2014 menetapkan tarif BK Mineral secara gradual terhadap tujuh jenis mineral, yaitu tembaga, besi, mangan, timbal, seng, ilmenite, dan titanium. Tarif ditetapkan $20 \%$ - $60 \%$ dan berlaku setiap semester, mulai 12 Januari 2014 sampai 31 Desember 2016. PMK 153/2014 kemudian memperpanjang pengenaan tarif $60 \%$ sampai 12 Januari 2017. Kebijakan itu dilatarbelakangi oleh keinginan pemerintah untuk mengendalikan penjualan bijih mineral, meningkatkan nilai tambah, dan menjaga ketersediaan sumber daya mineral di dalam negeri. Pemerintah mengerucutkan tujuan melalui PMK 6/2014 untuk menjamin ketersediaan bahan baku industri pengolahan dan pemurnian mineral. $^{2}$

Ada empat skema pengelolaan mineral yang terefleksikan dari perkembangan PMK BK Mineral. Pertama, pemerintah menginginkan hilirisasi industri mineral di dalam negeri, yang dilanjutkan dengan upaya menjamin ketersediaan bahan baku. ${ }^{3}$ Kedua, pemungutan BK dijadikan instrumen ekonomis untuk memaksa pelaku usaha melaksanakan kewajiban meningkatkan nilai tambah di dalam negeri. ${ }^{4}$ Ketiga, keinginan untuk mengusahakan potensi mineral secara mandiri dan andal..$^{5}$ Keempat, preferensi terhadap kepentingan dalam negeri dan keberlanjutan atas pemanfaatan kekayaan alam. Peraturan BK yang ditetapkan bersamaan dengan kebijakan yang mewajibkan pembangunan smelter untuk pengolahan dan/atau pemurnian mineral ikut mengafirmatif preferensi tersebut. Ada indikasi transformasi kebijakan dari kecendrungan eksploitasi dan pengutamaan ekspor menjadi kebijakan berbasis pembatasan eksploitasi untuk menjaga ketersediaan. ${ }^{6}$

Uraian di atas memperlihatkan tujuan positif yang ingin dicapai pemerintah melalui pemungutan BK sebagai instrumen. Namun, implementasinya mengundang reaksi kontra dari kalangan pelaku usaha sebagai addressat atau pihak yang diatur. Argumentasi umum yang dibangun, bahwa pemungutan BK yang dilaksanakan bersamaan dengan kewajiban membangun smelter akan menghambat keberlanjutan bisnis dan menghalangi masuknya investor. Dalam lingkup mikro, dua pelaku usaha besar, yaitu PT Newmont Nusa Tenggara (disingkat PTNNT) ${ }^{7}$ dan Freeport Mac Morran Indonesia, menolak penetapan BK ekspor mineral yang dianggap bertentangan dengan

Penelitian ini disusun saat Peraturan Menteri Keuangan No. 6/PMK. 011/2014 ditetapkan sehingga analisa dilakukan bertitik-tolak pada ketentuan-ketentuan di dalam PMK tersebut.

Lihat pada bagian Menimbang butir B PMK 6/2014.

Pilihan yang tepat bila melihat kondisi kekinian yang menunjukkan fluktuasi pertumbuhan industri pengolahan non migas. Pertumbuhan untuk tahun 2013 tercatat 6,10\% meleset dari sasaran sebesar 7,14\%. Capaian di tahun 2013 itu lebih rendah dari pertumbuhan di tahun 2012 sebesar 6,42\% dan tahun 2011 sebesar 6,74\%. Lihat pada Andrea S., "Pertumbuhan Meleset dari Target", Harian Kompas, 21 Februari 2014.

Kewajiban pemegang IUP dan IUPK tercantum dalam Pasal 95 Undang-Undang No.4 Tahun 2009 tentang Pertambangan Mineral dan Batubara (Lembaran Negara Tahun 2009 Nomor 4, Tambahan Lembaran Negara Republik Indonesia Nomor 4959).

Pararel dengan tujuan di dalam bagian Menimbang butir C Undang-Undang No.4 Tahun 2009 tentang Pertambangan Mineral dan Batubara (Lembaran Negara Tahun 2009 Nomor 4, Tambahan Lembaran Negara Republik Indonesia Nomor 4959).

Menurut Menteri Keuangan rasio yang digunakan bahwa dalam 40 tahun sudah $65 \%$ ekspor mineral dilakukan dalam bentuk raw material dan tanpa memperhatikan nilai tambah produk. Lihat dalam Anonim, "Pemerintah Persilakan Newmont dan Freeport Menggugat", www. bbc. co.uk/indonesia, diakses 25 Februari 2013.

PT Newmont Nusa Tenggara sudah berganti nama menjadi PT Amman Mineral Nusa Tenggara (PY AMNT) pasca masuknya PT Medco Energi Internasional Tbk sebagai pengendali dan pemegang saham mayoritas. 
kepastian hukum karena keduanya berpegang pada kontrak karya yang telah mengatur semua ketentuan pajak yang harus disetorkan kepada Pemerintah, dimana BK Ekspor tidak termasuk didalamnya. ${ }^{8}$ Sebagian kalangan berpendapat penetapan BK Mineral kontra yuridis dengan pengaturan ekspor di Peraturan Pemerintah (selanjutnya disebut PP) No. 23 Tahun 2010 yang hanya mensyaratkan prioritas pemenuhan kebutuhan dalam negeri sebelum melakukan ekspor. Tarif gradual mencapai $60 \%$ dari harga dianggap sebagai larangan ekspor terselubung.

Berdasakan paparan di atas, ada dua aspek dalam penetapan BK yang mengandung polemik, yaitu kesesuaiannya dengan asas kepastian hukum dan asas ekonomis. Kepastian hukum wajib terpenuhi dalam kebijakan pemerintah, terlebih berkaitan dengan pungutan negara. Identifikasi dan analisis terhadap tujuan penetapan BK diperlukan sebagai tahap awal untuk mengkonfirmasi terakomodir atau tidaknya kepastian hukum. Hal itu mengingat karakteristik BK yang hanya dapat dipungut berdasarkan tujuan tertentu sebagaimana diatur di dalam Pasal 2A ayat (2) Undang-Undang Nomor 17 Tahun 2006 tentang Kepabeanan (selanjutnya disebut UU Kepabeanan).

Tidak kalah penting adalah asas ekonomis (prinsip non-distorsi), yakni pemungutan negara tidak menimbulkan distorsi ekonomi di dalam masyarakat. Asas ini mendalilkan keseimbangan dalam kehidupan ekonomi tidak boleh terganggu akibat pungutan negara. Artinya, analisis tidak semata-mata didasarkan pada pendekatan yuridis karena BK merupakan suatu fenomena yang ada di masyarakat sehingga tidak ada tanpa didahului adanya kesatuan masyarakat.

Ada dua kepentingan dalam mendesain BK yang merupakan perikatan bersegi satu ini, yaitu kepentingan negara dan wajib bayar. Melalui asas ekonomis, keduanya akan dianalisis menggunakan pendekatan ekonomi, yaitu sisi mikro dan makro ekonomi. Rochmat Soemitro menyatakan bahwa segi makro ekonomi dianggap sebagai income negara, namun segi mikro ekonomi dianggap mengurangi income individu atau badan, daya beli, dan kesejahteraan, serta mengubah pola hidup atau usaha dari wajib bayar.

Perhatian terhadap kepentingan negara dan wajib bayar penting karena penetapan BK yang bersifat memaksa ini perlu memiliki rasionalisasi atas kekuatan berlakunya, baik secara yuridis (juristische geltung) maupun secara sosiologis (soziologische geltung). ${ }^{9}$ Pada akhirnya, penelitian ini diarahkan sebagai upaya untuk menentukan skema yang ideal dalam penatapan BK. ${ }^{10}$

Bertolak dari uraian di atas, terdapat tiga permasalahan dalam penelitian ini yakni: Pertama, apakah penetapan BK Mineral telah sesuai dengan asas kepastian hukum? Kedua, apakah penetapan BK Mineral telah sesuai dengan asas ekonomis? Ketiga, bagaimana skema penetapan BK Mineral yang ideal?

\section{B. Metode Penelitian}

Penelitian ini bersifat normatif-empiris, yang dilakukan dengan cara meneliti data sekunder yang diuji implementasinya melalui penelitian empiris yang bertitik tolak pada data primer. Perolehan data dilakukan melalui wawancara (interview), yang berfungsi untuk membuat deskripsi atau eksplorasi. Data-data tersebut dihimpun secara sistematis dan diklasifikasikan sesuai dengan pokok bahasan. Lebih lanjut, data dianalisis secara kualitatif yaitu sesuai dengan kualitas kebenarannya. Hasil penelitian dituangkan dalam bentuk deskripsi yang menjawab permasalahan rumusan masalah secara komprehensif.

Sudikno Mertokusumo, 2003, Mengenal Hukum Edisi Kelima, Liberty, Yogyakarta, hlm. 94-95.

Penilaian dan komunikasi merupakan tahap akhir yang dibutuhkan untuk memperoleh deskripsi yang komprehensif mengenai sistematika hukum atas suatu pengaturan, dalam Benjamin F. Crabtree dan William L. Miler, 1992, Doing Qualitative Research, Sage Publications, California, hlm. 162-163. 


\section{Hasil Penelitian dan Pembahasan}

\section{Kesesuaian Penetapan BK Ekspor Mineral} dengan Asas Kepastian Hukum

Asas kepastian hukum adalah "Asas dalam negara hukum yang mengutamakan landasan peraturan perundang-undangan, kepatutan, dan keadilan dalam setiap kebijakan penyelenggara negara". ${ }^{11}$ Adapun dalam pungutan negara kepastian hukum terwujud melalui pengaturan dalam undangundang yang tegas, jelas, dan tidak mengandung arti ganda atau berpeluang untuk ditafsirkan lain. ${ }^{12}$

Adam Smith dalam The Four Maxims mengistilahkan sebagai certainty, yaitu pungutan harus terang (certain) dan tidak mengenal kompromi (non arbitry). ${ }^{13}$ Berdasarkan uraian di atas, eksistensi asas kepastian hukum terdapat dan diakui dalam tataran pembentukan peraturan perundangundangan maupun dalam tataran penyelenggaraan negara di Indonesia.

a. Kesesuaian Penetapan BK Ekspor Mineral yang Dilakukan Oleh Penyelenggara Negara Dengan Peraturan Perundang-Undangan yang Berlaku

Tahap awal adalah mengidentifikasi dan menganalisis tujuan penetapan BK Mineral, karena jenis pungutan ini hanya dapat dipungut berdasarkan tujuan sebagaimana diatur dalam Pasal 2A ayat (2) UU Kepabeanan, yaitu untuk: menjamin terpenuhinya kebutuhan dalam negeri, melindungi kelestarian sumberdaya alam, mengantisipasi kenaikan harga yang cukup drastis dari komoditi ekspor tertentu di pasaran internasional; atau menjaga stabilitas harga komoditi tertentu di dalam negeri. ${ }^{14}$

Keempat tujuan yang berfungsi sebagai pembatasan penetapan BK Mineral bersifat alternatif berdasarkan penggunaan frasa "atau". ${ }^{15}$ Khusus bagi penetapan BK dalam PMK No. 6/2014 ditujukan untuk menjamin realisasi tujuan pertama dan kedua di atas, seperti disebutkan di konsiderans: "Sehubungan dengan perlunya menjamin ketersediaan bahan baku industri pengolahan dan pemurnian mineral serta menjaga kelestarian sumber daya alam, perlu mengenakan bea keluar terhadap produk mineral". ${ }^{16}$

Permasalahan hukum yang ingin diselesaikan melalui penetapan BK adalah besarnya jumlah ekspor mineral mentah, dan jikapun ada pengusaha yang mengekspor dalam bentuk konsentrat, kadarnya masih rendah dan pengolahannya belum sesuai dengan amanah UU Minerba. Data Kementerian Keuangan menunjukkan $65 \%$ ekspor mineral dilakukan dalam bentuk raw dalam 40 tahun terakhir dan tanpa memperhatikan nilai tambah produk. ${ }^{17}$

Berdasarkan wawancara dengan narasumber dari Badan Kebijakan Fiskal diperoleh pernyataan bahwa:

Pengolahan dilakukan sebatas demi menghindari PMK No. 75/2012 yang mengenakan BK 20\% terhadap ekspor bijih (raw) mineral. Kelemahan PMK ini tidak mengatur batas minum kadar, sehingga kadar di atas 0\% dianggap bukan bijih. Melihat hubungan antara peristiwa dan keberadaan hukum yang

11 Lihat asas ini misalnya pada Penjelasan Pasal 3 Undang-Undang Nomor 28 Tahun 1999 tentang Penyelenggaraan Negara yang Bersih dan Bebas dari Korupsi, Kolusi, dan Nepotisme (Lembaran Negara Republik Indonesia Tahun 1999 Nomor 75, Tambahan Lembaran Negara Republik Indonesia Nomor 3851).

2 Sony Devano dan Siti Kurnia Rahayu, 2006, Perpajakan: Konsep, Teori dan Isu, Kencana, Jakarta, hlm. 59.

3 Adam Smith dalam Santoso Brotodihardjo, 1991, Pengantar Ilmu Hukum Pajak, Refika Aditama, Bandung, hlm. 28.

Lihat pasal 2A ayat (2) Undang-Undang Nomor 17 Tahun 2006 tentang Perubahan Atas Undang-Undang Nomor 10 Tahun 1995 tentang Kepabean (Lembaran Negara Republik Indonesia Tahun 2006 Nomor 93, Tambahan Lembaran Negara Republik Indonesia Nomor 4661).

15 Lihat pada Lampiran I butir 263 Undang-Undang Nomor 12 Tahun 2011 tentang Pembentukan Peraturan Perundang-undangan (Lembaran Negara Republik Indonesia Tahun 2011 Nomor 82, Tambahan Lembaran Negara Republik Indonesia Nomor 5234).

16 Lihat pada Bagian Menimbang butir b Undang-Undang Nomor 12 Tahun 2011 tentang Pembentukan Peraturan Perundang-undangan (Lembaran Negara Republik Indonesia Tahun 2011 Nomor 82, Tambahan Lembaran Negara Republik Indonesia Nomor 5234).

17 Anonim, "Pemerintah Persilakan Newmont dan Freeport Menggugat”, www.bbc.co.uk/ indonesia, diakses pada 25 Februari 2014. 
saat itu berlaku, kondisi itu menjadi salah satu faktor yang memicu kenaikan tingkat ekspor hingga mencapai $300 \%$ sejak tahun 2010 hingga $2014 .{ }^{18}$

Indonesia merugi karena manfaat yang diterima negara dari penambangan sangat minim disebabkan sebagian besar pengolahan dan pemurnian dilakukan di luar negeri. Faktor itu berkontribusi bagi kemunduran industri dalam negeri, dimana pertumbuhan untuk tahun 2013 hanya 5,8\%, ${ }^{19}$ meleset dari sasaran $7,14 \%$ dan lebih rendah dari pertumbuhan tahun 2012 sebesar $6,42 \%$ dan $6,74 \%$ di tahun $2011 .{ }^{20}$ Ekses itu bersifat jangka panjang, mengingat karakteristik mineral sebagai sumber daya strategis namun tidak terbaharukan.

Oleh karenanya, Menteri Keuangan, Menteri Energi dan Sumber Daya Mineral serta Menteri Perdagangan berinisiatif untuk menutup kerugian dengan membuat peraturan pelaksana untuk menegakkan kewajiban pengolahan dan pemurnian dalam UU Mineral yang telah jatuh tempo di tahun 2014 yakni berupa PP No. 1 Tahun 2014 tentang Perubahan Kedua Atas PP No. 23 Tahun 2010 tentang Pelaksanaan Kegiatan Usaha Pertambangan Mineral Dan Batubara; Permen ESDM No. 1 Tahun 2014 tentang Peningkatan Nilai Tambah Mineral Melalui Kegiatan Pengolahan Dan Pemurnian Mineral Di Dalam Negeri; serta PMK 153/2014 dan PMK 6/2014. Adapun PMK BK Mineral berkedudukan sebagai instrumen fiskal untuk mengatur pengusaha agar mematuhi ketentuan-ketentuan dalam dua peraturan lainnya, sehinga bea tidak diberlakukan terhadap pengusaha yang patuh mencapai tahap pemurnian. Singkatnya, penetapan BK menjadi solusi yuridis untuk melindungi kelestarian SDA melalui pengendalian ekspor dan optimalisasi hilirisasi dalam negeri, sekaligus menjamin pemenuhan kebutuhan bahan baku dalam negeri.

Pemerintah membuat kebijakan pengendalian ekspor mineral secara berlapis sesungguhnya untuk menghindari konflik dengan pengusaha. Pertama, pemerintah melalui PP No. 1 Tahun 2014 menegaskan kewajiban pengolahan dan pemurnian berlaku terhadap seluruh pelaku usaha, baik yang beroperasi berdasarkan IUP, IPR, IUPK maupun Kuasa pertambangan, Surat Izin Pertambangan Daerah, Surat Izin Pertambangan Rakyat dan Kontrak Karya. Ketegasan diperlukan karena PP No. 23 Tahun 2010 mengecualikan Pemilik Kontrak Karya, yang kuantitas usahanya justru lebih besar, dari kewajiban itu. ${ }^{21}$ Melihat konstruksi pengaturan yang longgar, wajar bila sejak 2010 tingkat ekspor meningkat drastis hingga $300 \%$. Kelonggaran ditutup oleh PP No. 1 Tahun 2014 melalui Pasal 112C angka 1 yang memberlakukan kewajiban pengolahan dan pemurnian berlaku bagi pemegang kontrak karya. Dengan demikian dapat dikatakan PP No. 1 Tahun 2014 mengisi kekosongan dengan mempertimbangkan peraturan yang telah ada guna sebelumnya.

Kedua, melalui Permen ESDM No. 1 Tahun 2014 pemerintah mengafirmasi kewajiban pengolahan dan pemurnian sekaligus mengklasifikasikan kewajiban kontrak karya manjadi dua, yaitu:22 (1) Bagi

Berdasarkan wawancara dengan Djaka Kusmartata, narasumber dari Badan Kebijakan Fiskal Repulik Indonesia, pada 3 Juni Tahun 2014. Wahyu Daniel, "Setoran Pajak Tahun Ini Seret", www.detikfinance.com, diakses pada 27Juni 2014.

Andrea S., "Pertumbuhan Meleset dari Target", Harian Kompas, 21 Februari 2014.

Lihat Pasal 112 angka 3 Peraturan Pemerintah Nomor 23 Tahun 2010 tentang Pelaksanaan Kegiatan Usaha Pertambangan Mineral dan Batubara yang berbunyi "Kontrak karya dan perjanjian karya pengusahaan pertambangan batubara yang telah melakukan tahap kegiatan operasi produksi wajib melaksanakan pengutamaan kepentingan dalam negeri sesuai dengan ketentuan Peraturan Pemerintah ini”. Tidak jelas maksud frasa "sesuai dengan ketentaun PP" karena tidak ada satupun ketentuan dalam PP ini, kecuali di Pasal 112, yang mengatur pemegang Kontrak Karya sebagai addresat yang diharuskan untuk melaksanan pengutamaan kepentingan dalam negeri. Satu-satunya pengutamaan yang diperuntukkan bagi pemegang Kontrak Karya adalah kewajiban pemenuhan ketentuan pasokan dalam negeri.

22 Ketentuan Pasal 11 dan 12 angka 1 Permen ESDM Nomor 1 Tahun 2014 tentang Peningkatan Nilai Tambah Mineral Melalui Kegiatan Pengolahan dan Pemurnian Mineral di Dalam Negeri. 
Pemegang Kontrak Karya Mineral Bukan Logam dan Mineral Batuan diperbolehkan melakukan penjualan hasil pengolahan ke luar negeri setelah memenuhi batasan minimum pengolahan; dan (2) Bagi Pemegang Kontrak Karya Mineral Logam dapat melakukan penjualan ke luar negeri dalam jumlah tertentu hasil pengolahan termasuk hasil pemurnian setelah memenuhi batasan minimum pengolahan dan pemurnian sebagaimana Peraturan Menteri ini. Addressat penetapan BK Mineral dalam PMK No. 6/2014 adalah Pemegang Kontrak Karya Mineral Logam. Menurut hemat peneliti, preferensi pemerintah utamanya dalam melindungi Mineral Logam yang bernilai ekonomis lebih tinggi, sehingga proteksi berupa barrier diatur lebih ketat.

Itulah latarbelakang pemerintah Indonesia membuat kebijakan lapis ketiga, yaitu menetapkan BK terintegrasi dengan Permen ESDM Nomor 1 Tahun 2014. Skemanya adalah mengijinkan ekspor produk konsentrat hasil pengolahan dengan batas minimun dan maksimum yang telah diatur, ${ }^{23}$ namun dikenai disinsentif berupa pengenaan bea. Bea tidak dikenakan terhadap ekspor mineral yang telah dimurnikan. Hal ini untuk mengakselerasi pemurnian di dalam negeri. Pemegang Kontrak Karya juga telah diberi tengat waktu empat tahun untuk melalukan penyesuaian dengan UU Minerba, salah satunya melaksanakan pemurnian yang hingga sekarang tidak dilaksanakan.

Lebih lanjut, UU Kepabeanan telah mengatur tujuan pengenan BK secara limitatiif di Pasal 2A sehingga tujuan itu menjadi syarat sekaligus pembatasan penetapannya. Konstruksi demikian menjadikan pengaturannya dikualifikasikan dalam kelompok norma hukum berpasangan yang terdiri dari norma hukum primer dan sekunder. ${ }^{24}$ Penetapan BK Mineral sebagai norma hukum sekunder berkedudukan sebagai cara penanggulangan apabila norma hukum primer, yaitu UU Minerba, tidak dilaksanakan. Pemaparan di atas jelas menunjukkan kedudukan PMK No. 6/2014 sebagai bentuk disinsentif untuk mempercepat pengusaha merealisasikan kewajiban pengolahan dan pemurnian, melalui pembangunan fasilitas smelter.

Berdasarkan uraian di atas, penetapan BK Mineral oleh Menteri Keuangan sebagai penyelenggara negara dilakukan berlandaskan pada peraturan perundangundangan yang berlaku. Pemenuhan itu juga terkait dengan kedudukan PMK No. 6/2014 sebagai norma hukum sekunder yang tidak dapat berdiri sendiri. Indikator pertama dari asas kepastian hukum dengan demikian telah terpenuhi.

\section{b. Kejelasan dan Ketegasan Materi Muatan Serta Tidak Mengandung Arti Ganda}

Indikator kedua asas kepastian hukum ialah ketentuan pengaturan BK harus jelas (certain), tegas, dan tidak mengandung arti ganda sehingga tidak dapat ditafsirkan lain (unambigious). Ini untuk mencegah celahcelah (loopholes) yang dapat dimanfaatkan oleh pihak yang tidak patuh hukum sehingga menimbulkan ketidakpastian. ${ }^{25}$

Berdasarkan pendapat The New Encylopedia Britannica, unsur kejelasan (certain) penting untuk mewujudkan kepastian hukum, yaitu "Tax laws and regulations must be comprehensible to the taxpayer, they must be unambiguous and certain, both to the taxpayer and to the tax administrator" ${ }^{26}$

\footnotetext{
23 Skema demikian ilakukan agar kegagalan pengaturan ekspor dalam PMK Nomor 72/2012 yang tidak menyebutkan batas kadar minumum tidak terulang.

Budiman N.P.D. Sinaga, 2005, Ilmu Pengetahuan Perundang-Undangan, UII Press, Yogyakarta, hlm 13.

Eddhi Sutarto, 2010, Rekonstruksi Sistem Hukum Pabean Indonesia, Penerbit Erlangga, Jakarta, hlm. 36.

The New Encylopedia Britannica, 1988, Taxation, Encylopaedia Britannica Inc., London, hlm. 411.
} 
Mengasosiasikan itu, peneliti menyimpulkan dibutuhkan aturan BK yang terperinci sehingga prosedurnya jelas dan tegas antara pengusaha dan fiskus. Sommerfeld mengafirmasi kebutuhan aturan yang terperinci (advanced rulings) itu. $^{27}$

Aturan yang terperinci menurut Haula Rosdiana mencakup: siapa yang dikenakan (subjek); apa yang dikenakan (objek); dasar pengenaan; tarif; dan mekanisme pembayaran. ${ }^{28}$ Berdasarkan itu, penulis mengkonfirmasi pemenuhan indikator kedua dari asas kepastian hukum dengan melihat kejelasan dan ketegasan pengaturan unsur-unsur berikut: subjek, objek, dasar pengenaan, tarif, dan mekanisme pembayaran.

Unsur pertama, PMK No. 75/2012 dan perubahannya tidak eksplisit mengatur subjek karena PP No. 55 Tahun 2008 memposisikan PMK sebatas menjadi baju hukum atas penetapan barang ekspor yang dikenakan BK. ${ }^{29}$ Penetapan penting mengingat pengenaan BK bersifat diskresioner, seperti dijelaskan di atas. Adapun Peraturan $a$ quo, tidak mengatur subjek pajak karena istilah yang digunakan adalah pihak yang bertanggung jawab atas BK. Tersebut di Pasal 6 ayat (1) pihak yang bertanggung jawab adalah Eksportir, yaitu orang perseorangan atau badan yang melakukan ekspor. ${ }^{30}$ Design muatan dalam pasal tersebut berekses lanjutan karena subjek dan penanggung jawab secara konseptual berbeda.

Subjek pajak adalah orang pribadi atau badan yang dapat dikenakan pajak, ${ }^{31}$ sehingga sebatas potensi. Setiap orang atau badan yang memenuhi syarat subjektif, yaitu tinggal atau berkedudukan di Indonesia, menjadi subjek pajak. Bertransformasi menjadi orang atau badan yang oleh undang-undang perpajakan ditentukan untuk melakukan kewajiban perpajakan karena syarat-syarat objektif terpenuhi, yaitu ada sebab-sebab (keadaan, perbuatan, peristiwa). ${ }^{32}$ Berbeda dengan Penanggung dalam UU No. 19 Tahun 2000 diartikan sebagai orang pribadi atau badan yang bertanggung jawab atas pembayaran pajak, termasuk wakil yang menjalankan hak dan memenuhi kewajiban Wajib Pajak menurut ketentuan peraturan perundangundangan perpajakan. ${ }^{33}$ Penggunaan istilah penanggung oleh PP No. 55 Tahun 2008 tidak mengaburkan pengaturan subjek, karena esensi pihak yang harus melaksanakan kewajiban BK diatur jelas, yaitu Eksportir. Berdasarkan itu, maka unsur pertama terpenuhi.

Unsur kedua, adalah kejelasan dan ketegasan pengaturan mengenai objek. PMK No. 6/2014 jelas mengatur di Pasal 3 ayat (1) bahwa objek BK adalah barang ekspor berupa produk mineral hasil pengolahan. Makna Mineral hasil pengolahan diatur di ayat (2) bahwa "Produk mineral hasil pengolahan adalah sebagaimana tercantum dalam Lampiran yang tidak terpisahkan dari peraturan ini". Uraian di atas memperlihatkan unsur kedua telah terpenuhi.

Unsur ketiga, adalah kejelasan dan ketegasan pengaturan mengenai dasar penge-

Ray M. Sommerfeld, 1993, An Introduction To Taxation, Harcourt Brace Javanovich, hlm. 119.

Haula Rosdiana dan Edi Slamet Irianto, 2012, Pengantar Ilmu Pajak: Kebijakan dan Implementasi di Indonesia, RajaGrafindo Persada, Jakarta, hlm. 168.

29 Lihat Pasal 2 ayat (3) PMK Nomor 75 Tahun 2012 tentang Penetapan Barang Ekspor Yang Dikenakan Bea Keluar Dan Tarif Bea Keluar. Lihat Pasal 6 ayat (1) PMK Nomor 75 Tahun 2012 tentang Penetapan Barang Ekspor Yang Dikenakan Bea Keluar Dan Tarif Bea Keluar. Marihot Pahala Siahaan, 2010, Hukum Pajak Material, Graha Ilmu, Yogyakarta, hlm. 61.

32 Disaripatikan dari pengertian dalam Pasal 1 angka 2 Undang-Undang Nomor 19 Tahun 2000 tentang Perubahan Atas Undang-Undang Nomor 19 Tahun 1997 tentang Penagihan Pajak dengan Surat Paksa (Lembaran Negara Republik Indonesia Tahun 2000 Nomor 129, Tambahan Lembaran Negara Republik Indonesia Nomor 3897).

33 Lihat dalam Pasal 1 angka 3 Undang-Undang Nomor 19 Tahun 2000 tentang Perubahan Atas Undang-Undang Nomor 19 Tahun 1997 tentang Penagihan Pajak dengan Surat Paksa (Lembaran Negara Republik Indonesia Tahun 2000 Nomor 129, Tambahan Lembaran Negara Republik Indonesia Nomor 3897). 
naan BK. PMK No. 75/2012 tegas mengatur Harga Ekspor sebagai dasar pengenaan BK. Dijelaskan pula di Pasal 5 ayat (2) Harga Ekspor ditetapkan berdasarkan Harga Patokan Ekspor (HPE) yang ditetapkan secara periodik oleh Menteri Perdagangan. Apabila Harga Ekspor untuk periode berikutnya belum ditetapkan berlaku harga sebelumnya. Berdasarkan uraian di atas dapat diketahui unsur ketiga telah terpenuhi.

Unsur keempat, adalah kejelasan dan ketegasan pengaturan mengenai Tarif yang oleh UU Kepabeanan didefinisikan sebagai klasifikasi barang dan pembebanan bea masuk atau bea keluar. Oleh karena itu, Pasal 14 mengamanahkan untuk penetapan tarif BK, barang ekspor dikelompokkan berdasarkan sistem klasifikasi barang yang diatur lebih lanjut dengan Permen. Adapun sistem klasifikasi barang adalah suatu daftar penggolongan barang yang dibuat secara sistematis untuk mempermudah penarifan. ${ }^{34}$

PP No. 55 Tahun 2008 mengatur dua bentuk tarif, yaitu berdasarkan persentase dari Harga Ekspor (advolarum) dan secara spesifik. ${ }^{35}$ Apabila ditetapkan advolarum maka tarif tertinggi ialah sebesar $60 \%$ dari Harga Ekspor, sedangkan tarif spesifik berupa nominal tertentu yang besarnya equivalen dengan $60 \%$. Menkeu berwenang menetapkan bentuk tarif, setelah mendapat pertimbangan Menteri Perdagangan. PPhanya mengatur batas maksimum tarif namun tidak mengatur batas minimum, dan diserahkan kepada Menkeu untuk menentukan, bahkan bisa ditetapkan $0 \%$. Keharusan koordinasi sebagaimana dijelaskan diatas menunjukkan BK merupakan kebijakan lintas sektoral, sesuai dengan karakteristiknya sebagai instumen fiskal.

Norma di atas sudah diadopsi oleh PMK No. 6/2014 pada Pasal 3 yang menentukan tarif secara gradual dari $20 \%$ sampai $60 \%$ untuk enam jenis mineral logam yang dikenakan BK sebagaimana diatur dalam Lampiran PMK. Batas tarif tertinggi sudah selaras dengan PP No 55 Tahun 2008. Uraian di atas menunjukkan unsur keempat telah terpenuhi.

Unsur kelima, adalah kejelasan dan ketegasan pengaturan mengenai mekanisme pembayaran. Pemungutan BK menggunakan sistem self assessment sehingga eksportir melaksanakan kewajiban perpajakannya secara mandiri, mulai dari menghitung sampai membayar. Oleh karenanya, dibutuhkan peraturan yang jelas dan tegas sehingga mudah bagi pengusaha untuk mengoperasionalkan. Terkait itu, terhadap BK Mineral yang ditetapkan advolarum PP No. 55 Tahun 2008 sudah mengatur perhitungannya berdasarkan rumus:

Bea Keluar $=$ Tarif $\mathrm{x}$ Jumlah Satuan Barang x Harga Ekspor x Nilai Tukar Mata Uang

Setelah diketahui nilai terutang, eksportir membayar secara tunai paling lambat pada saat Pemberitahuan Pabean Ekspor, ${ }^{36}$ yaitu pernyataan yang dibuat untuk melaksanakan kewajiban pabean di bidang ekspor dalam bentuk tulisan di atas formulir atau data elektronik. Di PMK memang tidak disebutkan mekanisme pembayaran karena sudah diatur imperatif dalam PP No. 55 Tahun 2008. Uraian di atas menunjukkan unsur kelima terpenuhi. Elaborasi di atas memperlihatkan penetapan BK Mineral telah

34 Lihat Penjelasan Pasal 3 ayat (3) Peraturan Pemerintah Nomor 55 Tahun 2008 tentang Pengenaan Bea Keluar Terhadap Barang Ekspor (Lembaran Negara Republik Indonesia Tahun 2008 Nomor 1116, Tambahan Lembaran Negara Republik Indonesia Nomor 4886).

35 Lihat Pasal 3 ayat (3) Peraturan Pemerintah Nomor 55 Tahun 2008 tentang Pengenaan Bea Keluar Terhadap Barang Ekspor (Lembaran Negara Republik Indonesia Tahun 2008 Nomor 1116, Tambahan Lembaran Negara Republik Indonesia Nomor 4886).

36 Lihat Pasal 8 ayat (1) dan (2) Peraturan Pemerintah Nomor 55 Tahun 2008 tentang Pengenaan Bea Keluar Terhadap Barang Ekspor (Lembaran Negara Republik Indonesia Tahun 2008 Nomor 1116, Tambahan Lembaran Negara Republik Indonesia Nomor 4886). 
sesuai dengan indikator kedua asas kepastian hukum karena kelima unsur yang menjadi parameter telah terpenuhi

\section{c. Kesesuaian Antara Materi Muatan \\ Peraturan Perundang-Undangan yang Mengatur Penetapan BK Mineral dengan Peraturan Perun- dang-Undangan Lainnya}

Pada bagian ini analisis dilakukan untuk menilai kesesuaian bertitik-tolak pada jenis peraturan perundang-undangan sebagaimana diatur di Pasal 7 ayat (1) UU No. 12 Tahun 2011. Pertimbangannya, kekuatan hukum peraturan perundang-undangan berada dalam satu garis lurus dengan hierarkinya. Jenis peraturan perundang-undangan yang relevan dengan penelitian ini adalah UUDNRI 1945, UU, Tap MPR, dan PP. Penetapan BK merupakan kebijakan lintas sektoral sehingga ada beberapa peraturan yang terintegrasi dengannya, misalnya Permen ESDM. Peraturan ini adalah jenis selain yang diatur di Pasal 7, yang diakui keberadaannya dan mempunyai kekuatan hukum mengikat sepanjang diperintahkan oleh Peraturan Perundang-undangan yang lebih tinggi atau dibentuk berdasarkan kewenangan. ${ }^{37}$

\section{Pertama, kesesuaian dengan UUDNRI}

1945. Bagian ini dibangun berdasarkan wacana berwenangkah negara memungut BK menurut UUDNRI 1945. Perlu diketahui kedudukan BK dalam kehidupan bernegara, dapat dilihat pada memori penjelasan butir 2 UU Kepabeanan: “..., maka peraturan perundang-undangan ini sebagai bagian dari hukum fiskal ...". Artinya, UU memposisikan kedudukan bea sebagai bagian dari hukum fiskal. Kedudukan tersebut diafirmasi pula oleh John F. Due bahwa "Hukum fiskal berisikan sekumpulan norma yang berkaitan dengan penyelenggaraan pemerintahan yang hendak mewujudkan tujuan negaranya, sehingga daripadanya timbullah hak dan kewajiban yang dapat dinilai dengan uang". 38 Diasosiasikan dengan pendapat itu, maka identifikasi diarahkan pada pembuktian kesesuaian penetapan dengan tujuan negara. Sebagaimana Pasal 2A UU Kepabeanan menyebutkan bahwa BK ditetapkan untuk menjamin terpenuhinya kebutuhan dalam negeri dan melindungi kelestarian SDA. Uraian sebelumnya menunjukkan pengaturan pengelolaan mineral dan ekspor yang sebelumnya berlaku telah merugikan negara karena SDA strategis ini hanya menguntungkan sebagaian kalangan, terutama swasta. Selain itu, eskalasi kenaikan ekspor yang drastis turut mengganggu kelestarian SDA.

Dalam tataran empiris, penetapan BK Mineral sinkron dengan tujuan negara. Bahkan menjadi instrumen ekonomis untuk membantu pemerintahan mewujudkan tujuan negara, yaitu melindungi segenap bangsa Indonesia dan seluruh tumpah darah Indonesia dan untuk memajukan kesejahteraan umum. Perlindungan itu yang oleh John F. Due dikatakan menimbulkan hak dan kewajiban yang dapat dinilai dengan uang, berupa pengenaan BK.

Kesesuaian di atas juga terafirmasi melalui pengaitan penetapan BK dengan eksistensi Pasal 33 ayat (3), berbunyi "Bumi dan air dan kekayaan alam yang terkandung di dalamnya dikuasai oleh negara dan dipergunakan untuk sebesarbesar kemakmuran rakyat". Mahkamah Konstitusi sudah membuat tafsir resmi tentang hakikat "dikuasai oleh negara", yaitu mandat kepada negara untuk mengadakan kebijakan (beleid) dan tindakan pengurusan (bestuursdaad), pengaturan (regelendaad),

Lihat Pasal 8 ayat (2) Undang-Undang Nomor 12 Tahun 2011 tentang Pembentukan Peraturan Perundang-undangan (Lembaran Negara Republik Indonesia Tahun 2011 Nomor 82, Tambahan Lembaran Negara Republik Indonesia Nomor 5234).

John F. Due dan Ann F. Friedlaender, 1985, Keuangan Negara: Perekonomian Sektor Pemerintah, UII Press, Jakarta, hlm. 236 
pengelolaan (beheersdaad) dan pengawasan (toezichthoudensdaad) untuk tujuan sebesarbesarnya untuk kemakmuran rakyat. ${ }^{39}$

Penetapan BK Mineral oleh Pemerintah merupakan konkretisasi penguasaan negara, khususnya menjalankan fungsi pengaturan (regelendaad) melalui kewenangan regulasi. Terlebih Pasal 33 ayat (5) memberi keleluasaan lebih lanjut untuk mengatur pelaksanaan Pasal 33 dalam UU, termasuk UU Kepabeanan. Selaras juga dengan posisi bea yang berada dalam ranah hukum publik, yang oleh Sri Redjeki Hartono dikatakan "Hukum publik berawal dari kedaulatan (penguasaan) negara sampai pada fungsi pengaturan yang sifatnya memaksa". ${ }^{40}$ Uraian di atas menunjukkan penetapan BK sesuai dengan UUDNRI 1945.

Kedua, kesesuaian dengan TAP MPR Nomor IX/MPR/2001 Tentang Pembaruan Agraria Dan Pengelolaan SDA. Ketetapan berkedudukan sebagai landasan peraturan perundang-undangan mengenai pengelolaan SDA. ${ }^{41}$ Tujuannya untuk optimasi, keadilan, keberlanjutan dan ramah lingkungan untuk sebesar-besar kemakmuran rakyat. Oleh karenanya, prinsip yang ditegaskan adalah mengembangkan kepatuhan hukum dan optimasi partisipasi rakyat. Prinsip keberlanjutan juga diakui ndengan mengarahkan pengelolaan agar manfaatnya optimal bagi generasi sekarang dan mendatang, dengan tetap memperhatikan daya tampung dan dukung lingkungan. Berdasarkan itu, prinsip keterpaduan dan koordinasi antarsektor pembangunan dalam pelaksanaan pengelolaan SDA diakui. Pada konteks itu, penetapan BK dengan dua tujuan yang telah dijelaskan di atas, menjadi konkretisasi kebijakan pengelolaan SDA. Oleh karenanya, norma BK sinkron dan sinergi dengan TAP MPR Nomor IX/ MPR/2001.

Ketiga, kesesuaian dengan undangundang lainnya. Penjelasan umum butir 2 UU Kepabeanan menyebutkan “..., maka peraturan perundang-undangan ini sebagai bagiandarihukumfiskal harus dapatmenjamin perlindungan kepentingan masyarakat...". Artinya, pembuat UU tegas menyatakan bahwa pengenaan BK merupakan bagian dari kebijakan fiskal, sehingga tidak dapat berdiri sendiri. Pelaksanaannya pun sangat terait dengan ketentuan lain. ${ }^{42}$ Pada konteks penelitian ini, pengaturan $\mathrm{BK}$ terkait erat dengan peraturan perundang-undangan di bidang mineral, khususnya pengolahan dan pemurnian mineral (hilirisasi).

Melihat sejarah kelahirannya, UU No.4 Tahun 2009 tentang Pertambangan Mineral dan Batubara berperan sentral dalam penetapan BK Mineral. Tidak ada muatan yang tumpang tindih dengan penetapan BK, justru mengafirmasi. Berikut identifikasi materi muatan UU tersebut yang selaras dengan penetapan $\mathrm{BK}$ :

a. Pasal 2 mengatur mengenai pengelolaanpertambanganmineral yang berasaskan manfaat, keadilan, dan keseimbangan; serta keberpihakan kepadai kepentingan bangsa.

b. Pasal 3 mengatur pengelolaan mineral dan batubara yang diarahkan untuk mendukung pembangunan nasional yang berkesinambungan, sehingga tujuan pengelolaan demi menjamin efektivitas pelaksanaan dan pengendalian kegiatan usaha

Dalam Putusan Permohonan Judicial Review UU No.20 /2003 tentang Ketenagalistrikan Nomor 001-021-022/PUU-I/2003, UU No.22/2001 tentang Minyak dan Gas Bumi Nomor 002/PUU-I/2003, dan Putusan Uji materi UU No.7 Tahun 2004 tentang Sumber Daya Air Nomor 058059-060-063/PUU-II/2004.

to Sri Redjeki Hartono, 2007, Hukum Ekonomi Indonesia, Banyumedia Publishing, Malang, hlm. 38.

Lihat Pasal 1 TAP MPR Nomor IX/MPR/2001 Tentang Pembaruan Agraria Dan Pengelolaan Sumberdaya Alam.

Eddhi Sutarto, Op.cit., hlm. 13. 
pertambangan secara berdaya guna, berhasil guna, dan berdaya saing; serta menjamin tersedianya mineral sebagai bahan baku dan/atau sebagai sumber energi untuk kebutuhan dalam negeri.

c. Pasal 4 ayat (1) yang mengatur mineral sebagai sumber daya alam yang tak terbarukan merupakan kekayaan nasional yang dikuasai oleh negara untuk sebesar-besar kesejahteraan rakyat.

d. Pasal 5 ayat (1) mengatur kewenangan pemerintah mengendalikan produksi dan ekspor demi kepentingan nasional. Pegaturan kewenangan pemerintah dalam pengelolaan mineral, dan yang relevan dengan penelitian ini adalah: penetapan kebijakan nasional, pembuatan peraturan perundang-undangan, penetapan kebijakan pemasaran, serta pengembangan dan peningkatan nilai tambah kegiatan usaha pertambangan. Selanjutnya dikatakan kewenangan Pemerintah tersebut dilaksanakan sesuai dengan ketentuan peraturan perundangundangan, termasuk dalam hal penetapan BK Mineral.

e. Pengaturan penerimaan negara dalam Pasal 169 butir c, berbunyi "Ketentuan yang tercantum dalam pasal kontak karya dan perjanjian karya pengusahaan pertambangan batubara disesuaikan selambat-lambatnya satu tahun sejak UndangUndang ini diundangkan kecuali mengenai penerimaan negara". Lebih lanjut butir c berbunyi "Pengecualian terhadap penerimaan negara adalah upaya peningkatan penerimaan negara". Acontario, pasal ini membuka peluang perubahan pengaturan kewajiban perpajakan sepanjang berpengaruh positif terhadap penerimaan negara.

f. Pengaturan kewajiban melaku- kan pemurnian mineral bagi pemegang Kontrak Karya di Pasal 170, berbunyi "Pemegang kontrak karya yang sudah berproduksi wajib melakukan pemurnian selambat lambatnya lima tahun sejak UndangUndang ini diundangkan".

Keempat, kesesuaian dengan peraturan lain yang relevan, yaitu PP No. 1 Tahun 2014 Tentang Perubahan Kedua Atas PP No. 23 Tahun 2010 Tentang Pelaksanaan Kegiatan Usaha Pertambangan Mineral Dan Batubara dan Permen ESDM No. 1 Tahun 2014 Tentang Peningkatan Nilai Tambah Mineral Melalui Kegiatan Pengolahan Dan Pemurnian Mineral Di Dalam Negeri. Berikut materi muatan PP yang relevan dengan penetapan BK:

a. Pengaturan dalam Pasal 112 angka 3, berbunyi "Kontrak karya dan perjanjian karya pengusahaan pertambangan batubara yang telah melakukan tahap kegiatan operasi produksi wajib melaksanakan pengutamaan kepentingan dalam negeri sesuai dengan ketentuan peraturan perundang-undangan".

b. Pengaturan dalam Pasal 112C angka 1 , berbunyi "Pemegang kontrak karya sebagaimana dimaksud dalam Pasal 170 UU No. 4 Tahun 2009 tentang Pertambangan Mineral dan Batubara wajib melakukan pemurnian hasil penambangan di dalam negeri".

c. Pengaturan dalam Pasal 112C angka 5, berbunyi "Ketentuan lebih lanjut mengenai pelaksanaan pengolahan dan pemurnian serta batasan minimum pengolahan dan pemurnian 
diatur dengan Peraturan Menteri".

Selain itu, penetapan BK Mineral terkait dengan materi muatan Permen ESDM No. 1 Tahun 2014 berikut:

a. Pasal 2 yang mengatur cara peningkatan Nilai Tambah komoditas tambang Mineral Logam melalui pengolahan dan pemurnian.

b. Pengaturan dasar pertimbangan dalam melakukan pengolahan dan pemurnian dalam Pasal 3 ayat (2) berdasarkan pertimbangan: memiliki sumber daya dan cadangan Bijih dalam jumlah besar; untuk mendorong peningkatan kapasitas produksi logam di dalam negeri; memberikan efek ganda bagi negara baik secara ekonomi dan sosial dan budaya; untuk meningkatkan penerimaan negara.

Identifikasi di atas memperlihatkan kesesuaian materi muatan peraturan lainnya dengan penetapan BK Mineral. Pararel dengan kedudukan PMK BK Mineral sebagai norma sekunder yang menegakkan norma primer, dalam hal ini sebagai instrumen fiskal berupa disinsentif. Berdasarkan itu dapat dikatakan penetapan BK Mineral telah sesuai dengan asas kepastian hukum.

\section{Kesesuaian Penetapan BK Ekspor Mineral Dengan Asas Ekonomis}

Asas ekonomis oleh E.R.A. Seligman disebut Innocuity Principle, menekankan agar pemungutan tidak bersifat destruktif. Cocok untuk menilai relasi dengan pelaku usaha karena asas ini mengharapkan pungutan negara tidak menghalangi rakyat mencari kesejahteraan. ${ }^{43}$ Adapun Rochmat Soemitro berpandangan bahwa pungutan yang dibayar dari penghasilan rakyat (volkeinkomen) harus memenuhi syarat: ${ }^{44}$ tidak mengurangi kekayaan rakyat; tidak menghalangi kelancaran perdagangan dan perindustrian; dan tidak merugikan rakyat.

Doktrin tersebut menunjukkan dalam asas ekonomis terkandung prinsip non-distorsi, yakni pemungutan BK tidak boleh menimbulkan distorsi dalam masyarakat, terutama distorsi ekonomi. ${ }^{45}$ Pengenaan seharusnya tidak menimbulkan kelesuan ekonomi. Singkatnya, asas ekonomis mendalilkan bahwa keseimbangan dalam kehidupan ekonomi tidak boleh terganggu akibat negara melakukan pemungutan $\mathrm{BK} .{ }^{46}$

Pendekatan yuridis memposisikan BK sebagai perikatan bersegi satu yang timbul karena undang-undang yang mewajibkan orang pribadi atau badan yang memenuhi tatbestand yang ditentukan oleh UU, untuk membayar jumlah tertentu kepada negara. Pemenuhannya tidak mendapat imbalan namun dapat dipaksakan. Lebih lanjut, dalam men-design perikatan, ada dua kepentingan yang perlu diperhatikan, yaitu kepentingan negara dan pembayar.

Pertimbangan terhadap dua kepentingan di atas dilakukan melalui pendekatan ekonomi, yang melihat BK dari sisi mikroekonomi dan makroekonomi. Disaripatikan dari pendapat Rochmat Soemitro, BK dari segi makro ekonomi merupakan income negara. Pada segi mikro ekonomi BK mengurangi income perusahaan, daya beli, kesejahteraan, dan mengubah pola operasi usaha. ${ }^{47}$

Pemungutan BK seyogyanya memadukan dua pendekatan itu, yang memperhatikan perusahaan dan kepentingan negara secara simultan. Kemampuan memikul beban pungutan perlu diperhatikan, meskipun hasilnya akan kembali untuk memenuhi kebutuhan bersama. ${ }^{48}$ Hal tersebut bertitik tolak

\footnotetext{
E.R.A. Seligman dalam Y. Sri Pudyatmoko, 2009, Pengantar Hukum Pajak, Andi Offset, Yogyakarta, hlm. 46.

Rochmat Soemitro, 1977, Dasar-Dasar Hukum Pajak dan Pajak Pendapatan 1944, Eresco, Bandung, hlm. 21-22.

Y. Sri Pudyatmoko, Op.cit., hlm. 54.

Santoso Brotodihardjo, Op.cit., hlm. 42.

Rochmat Soemitro, 1992, Pengantar Singkat Hukum Pajak, Eresco, Bandung, hlm. 13.

Y. Sri Pudyatmoko, Op.cit, hlm. 32.
} 
dari pemahaman bahwa BK akan menjadi peralihan kekayan dari anggota masyarakat kepada negara sehingga akan ada dampak ekonomis yang timbul.

Bagi PTNNT yang dijadikan responden, substansi PMK No. 6/2014 belum merepresentasikan asas ekonomis. Itu tidak lepas dari keterkaitan antara pembayaran BK dengan pencapaian batas kadar minimum mineral. Ketentuan mengenai kadar bermuara pada pelaksanaan kewajiban pengolahan dan pemurnian mineral oleh pengusaha. Permasalahan terjadi karena makna pengolahan berbeda antara para pihak, dimana menurut perusahaan pengolahan ditujukan agar produk dapat dijual tapi tidak sampai pada batas minimum yang diatur pemerintah, yang sebenarnya telah masuk tahap pemurnian.

Kondisi di atas seperti siklus masalah, karena pengolahan dan pemurnian sampai batas minimum yang diharapkan oleh pemerintah secara ekonomis tidak menguntungkan. Itu terjadi karena teknologi pengolahan yang digunakan pengusaha saat ini mengunakan downstream metals processing fasilities, sedangkan untuk mencapai kadar yang ditetapkan oleh PMK No. 6/2014 maka mineral harus dimurnikan melalui infrastruktur yang disebut smelter.

Pembangunan smelter menjadi masalah bagi perusahaan yang rasio produksinya (bahan baku) jauh dibawah kapasitas smelter yang secara ekonomis menguntungkan. Kondisi eksisting dan prediksi lima tahun kedepan di PTNNT dapat dijadikan ilustrasi. Realisasi produksi konsentrat perusahaan di tahun 2013 sebesar 400.000 ton, 2014 sebesar 450.000 ton, dan tahun 2015 diprediksi sebesar 600.000 ton. Prediksi untuk tahun 2016 sebesar 750.000 ton, 2017 sebesar 500.000 ton, dan 2018 sebesar 250.000 ton. Padahal, smelter harus berkapasitas \pm 1.200 .000 ton agar menguntungkan. Perusahaan yang membangun smelter artinya harus menyediakan pasokan bahan baku sebesar 1.200.000 ton, jauh di bawah jumlah konsentrat yang diproduksi PTNNT. Singkatnya, kebijakan itu mendorong perusahaan pada kondisi devisit yang potensial merugikan, bahkan membuat stagnasi usaha.

Pembangunan smelter merupakan invenstasi besar_US \$1.5-2.5 Milyar (Rp. 18-30 triliun) dengan manfaat yang bersifat jangka panjang. Di sisi lain, perusahaan yang komoditasnya belum dimurnikan wajib membayar BK dengan tarif gradual 20\%$60 \%$ sesuai dengan waktu dan jenis mineral yang diekspor. Menggunakan tarif yang berlaku sekarang dan asumsi dapat melakukan ekspor, nilai selisih yang diperoleh perusahaan dari harga ekspor akan terus berkurang seiring dengan peningkatan tarif per semester, misalnya: untuk ekspor produk tembaga dalam periode 1 Juli-31 Desember 2015 berlaku tarif 40\%; periode 1 Januari-30 Juni 2016 berlaku tarif 50\%; dan periode 1 Juli 2016-12 Januari 2017 berlaku tarif $60 \%$. Artinya selisih yang diperoleh perusahaan dari harga ekspor terus berkurang pararel dengan peningkatan tarif dari $60 \%$ terus menurun hingga tersisa $40 \%$. Selisih nilai penjualan itu masih harus digunakan untuk menutup biaya operasi dan investasi pembangunan smelter.

Deskripsi di atas menunjukkan skema BK Mineral dalam PMK No. 6/2014 belum sesuai dengan asas ekonomis karena: ${ }^{49}$ Pertama, Menghambat kelancaran produksi dan perdagangan karena laba akan terus berkurang pararel dengan peningkatan tarif, bahkan potensial membuat perusahaan gulung tikar. Kedua, Tarif gradual yang terus meningkat akan menghalangi pengusaha yang patuh membangun smelter dalam usahanya mencapai laba optimal. Ketiga, Potensial merugikan kepentingan masyarakat yang akan mengalami pemutusan hubungan kerja apabila perusahaan vakum.

Berkaca pada kondisi di atas, asas ekonomis perlu diakomodir karena asas ini memperlihatkan tendensi perhatian pemerintah pada keadaan masyarakat. 


\section{Skema Penetapan BK Ekspor Mineral yang Ideal}

Penetapan BK Mineral dilatarbelakangi oleh semangat pemerintah untuk melindungi kekayaan alam dan kepentingan nasional. Sasaran itu dikonkretkan menjadi larangan ekspor bijih serta peningkatan nilai tambah mineral melalui pengolahan dan pemurnian di dalam negeri atau yang disebut hilirisasi.

Permasalahannya, tujuan pemerintah serta urgensi dikeluarkannya kebijakan berbeda dengan perspektif pengusaha yang menjalankan operasi berbasis pada Kontrak Karya. Klausula Kontrak Karya PTNNT dapat dijadikan objek studi, dimana Pasal 10 butir 3 menyatakan "Perusahaan harus mengolah bijih untuk menghasilkan suatu konsentrat yang dapat dipasarkan". Mendasarkan itu, pengusaha berpendapat bukan raw yang diekspor karena pengolahan sudah dilakukan meskipun dengan kadar yang rendah.

Berbeda dengan perspektif pemerintah dimana pengolahan dimaknai: "Kegiatan usaha pertambangan untuk meningkatkan mutu mineral dan/ atau batubara serta untuk memanfaatkan dan memperoleh mineral ikutan". ${ }^{50}$ Hal ini berseberangan dengan pemaknaan sederhana versi Kontrak Karya: "Memproses bijih sesudah ditambang untuk menghasilkan setidak-tidaknya suatu konsentratyang dapat dipasarkan". ${ }^{51}$ Berdasarkan itu perusahaan berpendapat tidak selayaknya dikenakan BK karena berdasarkan kontrak pihaknya tidak diharuskan melakukan pemurnian. Akibat kontroversi tersebut, kepatuhan terhadap PMK tidak serta merta dapat langsung dibangun.

Selain itu, tidak ada pengaturan BK di dalam Kontrak Karya. Bahkan ada ketentuan bahwa perusahaan tidak wajib membayar lain-lain pajak, bea-bea, pungutan-pungutan, sumbangansumbangan, pembebanan-pembebanan, atau biaya-biaya sekarang maupun dikemudian hari yang dipungut atau dikenakan atau disetujui oleh Pemerintah, selain dari yang ditetapkan dalam Kontrak Karya. Berdasarkan klausul itu, pengusaha akan memperjuangkan pengecualian dari penetapan pungutan yang diberlakukan setelah Kontrak ditandatangani.

Pengenaan pungutan negara di sebuah kontrak jangka panjang hampir pasti melibatkan tarik menarik kepentingan, oleh karena itu, penetapan BK disamping menyentuh ranah hukum publik juga menyentuh ranah hukum perdata. Dengan berpegang pada pemahaman hukum sebagai sistem, maka ada beberapa alternatif untuk mengintegrasikan dua sisi yang berlawanan, diantaranya melihat pada doktrin yang berlaku. Doktrin Paul Scholten relevan untuk itu, bahwa menurutnya hukum perdata harus dipandang sebagai hukum umum (lex generalis), kecuali jika hukum publik telah menetapkan peraturan yang menyimpang daripadanya. ${ }^{52}$ Berdasarkan itu, pengenaan BK menegasikan keberlakuan klausula dalam Kontrak Karya yang memberikan imunitas bagi pengusaha terhadap keberlakuan pungutan yang ditetapkan setelah kontrak ditandatangani.

Penetapan BK yang lebih superior keberlakuannya daripada Kontrak memang akan berimbas pada kemampuan ekonomis pengusaha. Terkait itu, Santoso Brotodihardjo mengemukakan pendapat bahwa bagaimana penetapan pajak dari pemerintah akan berpengaruh terhadap kondisi ekonomi dan sosial sehingga tidak mungkin pajak diharapkan bersifat netral. ${ }^{53}$

Terlepas dari ketidaknetralannya, kebijakan penetapan BK Mineral perlu mengakomodasi keadilan bagi pengusaha dan negara secara simultan. Adil bagi negara ialah memaksimalkan kekayaan alam demi kepentingan nasional, selain juga memperhatikan keadaan subjektif dari perusahaan. Pendapat ini potensial menimbulkan reaksi di kalangan yang berpendapat BK merupakan pajak

\footnotetext{
50 Pasal 1 angka 20 Undang-Undang No.4 Tahun 2009 tentang Pertambangan Mineral dan Batubara (Lembaran Negara Tahun 2009 Nomor 4, Tambahan Lembaran Negara Republik Indonesia Nomor 4959).

Pasal 1 butir 16 Kontrak Karya PT. Newmont Nusa Tenggara dengan Pemerintah.

Santoso Brotodihardjo, Op.cit., hlm. 11.

Ibid., hlm. 21-23.
} 
objektif, sehingga titik tolak pengenan melihat pada objek, yaitu adanya ekspor mineral, tanpa melihat keadaan penanggungnya (subjek). Argumentasi penulis, meskipun dikategorikan sebagai pajak objektif, namun UU Kepabeanan sudah mengatur adanya jaminan mewujudkan keadilan dalam penetapan Bea Keluar, ${ }^{54}$ sehingga harus dikomodir.

Berdasarkan uraian di atas, keadilan dapat menjadi panduan untuk membentuk bangun kebijakan yang ideal. Penulis menggunakan pendapat L. J. Van Apeldoorn sebagai landasan sehingga inti keadilan yang dimaksud dalam penelitian ini adalah mengadakan keseimbangan antara kepentingan-kepentingan yang dilindungi sehingga tiap-tiap orang mendapat apa yang menjadi haknya masing-masing sebagaimana mestinya.

Dalam perspektif perpajakan, ada beberapa argumentasi yang menjelaskan arti penting keadilan melalui cara-cara yang menjadi esensinya, yang dapat diarahkan untuk mengadakan keseimbangan antar kepentingan-kepentingan. Cara pertama merealisasikan keadilan dengan mengusahakan pemungutan BK dilakukan secara umum dan merata. Cara ini sesuai dengan prinsip equality before the law, bahkan termuat dalam UUDNRI 1945. Prinsip ini diaplikasikan melalui pemberlakuan tanpa kecuali kepada semua pihak yang berada dalam keadaan yang sama. Merujuk pada prinsip ini, penetapan BK sudah diberlakukan terhadap seluruh eksportir produk mineral olahan (konsentrat). Dilihat dari sisi ini penetapan BK Mineral telah merepresentasikan satu bagian dari prinsip keadilan.

Cara kedua adalah mengusahakan pembagian tekanan beban BK seimbang dengan kemampuan membayar masing-masing pengusaha. Terkait itu, ada beberapa landasan konseptual yang dapat digunakan untuk mengatur kemampuan membayar. Landasan pertama adalah teori daya pikul, yang mendalilkan agar setiap orang membayar pajak sesuai daya pikul masing-masing. Daya pikul menurut De Langen sebagaimana dikutip oleh Rochmat Soemitro adalah: "Kekuatan untuk memikul suatu beban atas apa yang tersisa, setelah seluruh penghasilannya dikurangi dengan pengeluaran-pengeluaran yang mutlak untuk kehidupan primer diri sendiri dan anggota keluarganya". ${ }^{55}$ Diterapkan pada pengenaan BK, maka kekuatan untuk menyerahkan uang kepada negara baru ada jika kebutuhan primer untuk operasional usaha telah terpenuhi. Artinya, sisa dari pemenuhan kebutuhan itu yang disebut sebagai daya pikul.

Landasan kedua adalah asas equality and equity, seperti dikemukakan Adam Smith bahwa asas ini menghendaki agar negara tidak diskriminatif dengan memberi perlakuan yang sama terhadap orang dalam kondisi yang sama. ${ }^{56}$ Lebih lanjut, IBFD membagi asas kesamaan menjadi dua, pertama ialah horizontal equity, yang bermakna bahwa orang-orang dalam kondisi sama maka perlakuan perpajakannya pun sama. ${ }^{57}$ Sebaliknya pada vertical equity bermakna terhadap orangorang yang berada dalam kondisi yang berbeda maka perlakuan perpajakannya pun berbeda. ${ }^{58}$

Melalui uraian di atas, penulis ingin menyatakan bahwa prinsip keadilan perlu diakomodir dalam penetapan BK. Hal yang rasional diterapkan karena secara konseptual berbagai asas dan teori di atas dapat mendukung keberlakuannya. Penulis tidak mengusulkan penghapusan BK atau penyesuaiaan pengenaan sampai jangka waktu Kontrak habis, karena justru akan mencederai rasa keadilan masyarakat.

Alternatif lainnya ialah kebijakan tax cut atau penurunan beban pajak. Skema ini berintikan keseimbangan antar berbagai kepentingan sehingga setiap pihak mendapat apa yang menjadi haknya sebagaimana mestinya. Penurunan beban pajak

\footnotetext{
Bagian menimbang Undang-Undang Nomor 17 Tahun 2006 tentang Perubahan Atas Undang-Undang Nomor 10 Tahun 1995 tentang Kepabean (Lembaran Negara Republik Indonesia Tahun 2006 Nomor 93, Tambahan Lembaran Negara Republik Indonesia Nomor 4661).

Rochmat Soemitro, 1992, Pengantar Singkat Hukum Pajak, Op.cit., hlm. 31.

Sri Pudyatmoko, 2009, Op.cit., hlm. 48.

Ibid., hlm. 15.

Haula Rosdiana, et al., Op.cit., hlm 121.
} 
merupakan bagian dari mekanisme fiskal yang disebut supply-side policies, yaitu kebijakan untuk meningkatkan kinerja pasar dengan cara menaikkan kapasitas ekonomi untuk meningkatkan kapabilitas produksi. ${ }^{59}$ Diterapkan dalam topik ini, penurunan beban pajak diakomodasi dalam PMK 153/2014. Peraturan ini menyebutkan bagi eksportir yang membangun $^{60}$ atau bekerjasama membangun fasilitas pemurnian diberi pengurangan tarif yang diklasifikasi berdasarkan tingkat kemajuan pembangunan fasilitas pemurnian mineral sesuai dengan persentase nilai serapan biaya. ${ }^{61}$ Adapun kategorinya: Tahap I untuk tingkat kemajuan pembangunan sampai 7,5\%; Tahap II untuk pembangunan dengan tingkat kemajuan $\geq 7,5 \%$ $30 \%$; dan Tahap III untuk tingkat kemajuan $\geq 30 \%$. Pengurangan tarif untuk addressat di atas sangat signifikan dan tarif dipangkas menjadi besaran seperti diuraikan pada tabel di bawah ini.

Tabel 1. Tarif Bea Keluar Hasil Pengolahan Eksportir yang Membangun atau Bekerjasama Membangun Fasilitas Pemurnian

\begin{tabular}{|c|c|c|c|c|c|}
\hline \multirow{3}{*}{$\begin{array}{l}\text { Tingkat Kema- } \\
\text { juan Pemban- } \\
\text { gunan }\end{array}$} & \multicolumn{5}{|c|}{ Tarif Bea Keluar (\%) } \\
\hline & \multirow{2}{*}{$\begin{array}{c}\frac{2014}{\text { Berlaku s/d }} \\
31 \text { Dec }\end{array}$} & \multicolumn{2}{|c|}{2015} & \multicolumn{2}{|c|}{ 2016-2017 } \\
\hline & & $\begin{array}{c}\text { Sejak } 1 \text { Jan- } \\
\text { 30 Juni }\end{array}$ & $\begin{array}{c}\text { Sejak } 1 \text { Jul- } \\
31 \text { Dec }\end{array}$ & $\begin{array}{c}\text { Sejak } 1 \text { Jan 2016- } \\
\text { 30 Juni } 2016\end{array}$ & $\begin{array}{c}\text { Sejak } 1 \text { Jul 2016- } \\
12 \text { Jan } 2017\end{array}$ \\
\hline Tahap I & $7,5 \%$ & $7,5 \%$ & $7,5 \%$ & $7,5 \%$ & $7,5 \%$ \\
\hline Tahap II & $5 \%$ & $5 \%$ & $5 \%$ & $5 \%$ & $5 \%$ \\
\hline Tahap III & $0 \%$ & $0 \%$ & $0 \%$ & $0 \%$ & $0 \%$ \\
\hline
\end{tabular}

Sumber : PMK No. 6 Tahun 2014 tentang Perubahan Kedua Atas Peraturan Menteri Keuangan No.75/ PMK.011/2012 tentang Penetapan Barang Ekspor yang Dikenakan Bea Masuk dan Bea Keluar

Tarif gradual dalam PMK No. 6/2014 tetap diberlakukan bagi eksportir yang tidak beritikad baik melakukan pemurnian. Pengurangan tarif tidak bertentangan dengan UU Kepabeanan dan PP No. 55 Tahun 2008 karena penetapan BK memang diposisikan sebagai norma yang diskresioner. Kewenangan pengaturan lebih lanjut juga diserahkan kepada Menkeu, termasuk menentukan tarif, sepanjang tidak melebihi batas tertinggi sebesar $60 \%$.

Penurunan tarif dalam PMK 153/2014 menjadi jalan tengah yang menyatukan gap antara kepentingan ekonomis pengusaha dengan negara, sekaligus sebagai akomodasi prinsip keadilan. Nemun demikian, penulis berpendapat perlu ada review terhadap besaran tarif dalam tabel 2 di atas.
Ada perspektif yang perlu dipertimbangkan, yaitu karakteristik BK sebagai pajak tidak langsung sehingga dimungkinkan ada pengalihan beban pajak (shifting forward), baik sebagian maupun seluruhnya kepada pihak pembeli. Apabila tarif diturunkan menjadi sangat rendah, dikhawatirkan tujuan pemerintah menerapkan BK untuk mengakselerasi pemurnian mineral tidak tercapai. Terobosan itu akan efektif bila diikuti dengan instrumen untuk mencegah moral hazard akibat pengurangan tarif. Oleh karena itu, penulis mengusulkan ada kalkulasi pengaruh relatif dari pengurangan tarif dengan realisasi pembangunan fasilitas pemurnian. Adapun secara garis besar John F. Due memperkenalkan pendekatan kalkulasi berikut: ${ }^{62}$ Pertama, hingga berapa besar investasi akan bertambah sebagai reaksi

Ibid., hlm. 85-85.

60 Pembangunan di atas meliputi penempatan jaminan kesungguhan, Conditional Sales Purchase Agreement (CSPA) atau dokumen yang menunjukkan tersedianya pasokan bahan baku, fase studi, perijinan, penguasaan lokasi, penyiapan infrastruktur, rekayasa dasar, pengadaan peralatan, konstruksi, mechanical completion, commissioning, dan produksi.

61 Disaripatikan dari ketentuan ayat (1) dan ayat (2) Pasal 4A PMK No. 153/ PMK.011/2014 Tahun 2014 tentang Perubahan Ketiga Atas Peraturan Menteri Keuangan No. 75/PMK.011/2012 tentang Penetapan Barang Ekspor yang Dikenakan Bea Keluar dan Tarif Bea Keluar.

62 John F. Due, op.cit, hlm. 363. 
terhadap pengurangan tarif? Kedua, hubungan accelerator, yaitu berapa banyak investasi akan bereaksi terhadap pertambahan tertentu akibat tarif yang diberlakukan? Dan Ketiga, reaksi investasi perusahaan-perusahaan dinilai dari tingkat kecepatan hasil investasi.

Berdasarkan itu, penurunan tarif secara objektif dapat menjadi bentuk kompromi atas gap antara kepastian hukum dan pertimbangan ekonomis. Hal ini sesuai dengan pernyataan John F. Due bahwa "Struktur perpajakan yang optimal sebenarnya mencerminkan suatu kompromi antara berbagai sikap orang-orang tentang akibat-akibat dan tujuan-tujuan". ${ }^{63}$

\section{Kesimpulan}

Penetapan BK Mineral telah sesuai dengan asas kepastian hukum karena ketiga indikator telah ditentukan terpenuhi. Pertama, penetapan BK oleh penyelenggara negara (Menteri Keuangan) dilakukan berlandaskan pada peraturan perundangundangan yang berlaku. Kedua, materi muatannya telah jelas, tegas, dan tidak mengandung arti ganda sehinga tidak memberi peluang untuk ditafsirkan lain. Ketiga, materi muatan antar peraturan perundang-undangan yang mengatur penetapan BK Mineral tidak tumpang dengan peraturan perundang-undangan lainnya.
Di sisi lain, penetapan BK Mineral belum sesuai dengan asas ekonomis karena penetapannya menimbulkan ekses berikut: Pertama, menghambat lancarnya lancarnya produksi dan perdagangan karena laba yang terus berkurang pararel dengan peningkatan tarif, bahkan potensial membuat perusahaan gulung tikar. Kedua, tarif gradual yang terus meningkat akan menghalangi pengusaha yang patuh membangun smelter dalam usahanya mencapai laba optimal. Ketiga, Potensial merugikan kepentingan masyarakat banyak yang akan mengalami pemutusan hubungan kerja apabila perusahaan terus vakum.

Melihat gap tesebut, maka skema yang ideal di dalam penatapan BK Ekspor Mineral adalah dengan memasukkan pertimbangan realisasi keadilan untuk mengusahakan agar keseimbangan antar kepentingan negara-pengusaha dapat tercapai. Kebijakan penurunan beban pajak dapat diberlakukan, khusus untuk perusahaan yang membangun smelter. Penilaian objektif terhadap itikad tersebut dapat mendasarkan pada progres capaian, baik actual physical construction, actual cost spent, maupun committed cost. Meskipun begitu, terhadap perusahan yang tidak patuh membangun smelter tetap diberlakukan tarif menurut PMK No. 6/2014.

\section{DAFTAR PUSTAKA}

\section{A. Buku}

Crabtree, Benjamin F. dan Miler, William L., 1992, Doing Qualitative Research, Sage Publications, California.

Devano, Sony dan Rahayu, Siti Kurnia, 2006, Perpajakan: Konsep, Teori dan Isu, Kencana, Jakarta.

Due, John F. dan Friedlaender, Ann F., 1985, Keuangan Negara: Perekonomian Sektor Pemerintah, UII Press, Jakarta.
Hartono, Sri Redjeki, 2007, Hukum Ekonomi Indonesia, Banyumedia Publishing, Malang.

Mertokusumo, Sudikno, 2003, Mengenal Hukum Edisi Kelima, Liberty, Yogyakarta.

Pudyatmoko, Y. Sri, 2009, Pengantar Hukum Pajak, Andi Offset, Yogyakarta.

Rosdiana, Haula dan Irianto, Edi Slamet 2012, Pengantar Ilmu Pajak: Kebijakan dan Implementasi di Indonesia, RajaGrafindo Persada, Jakarta.

63 Ibid, hlm. 488. 
Santoso Brotodihardjo, 1991, Pengantar Ilmu Hukum Pajak, Refika Aditama, Bandung.

Siahaan, Marihot Pahala, 2010, Hukum Pajak Material, Graha Ilmu, Yogyakarta.

Sinaga, Budiman N.P.D., 2005, Ilmu Pengetahuan Perundang-Undangan, UII Press, Yogyakarta.

Soemitro, Rochmat, 1977, Dasar-Dasar Hukum Pajak dan Pajak Pendapatan 1944, Eresco, Bandung. , 1992, Pengantar Singkat

Hukum Pajak, Eresco, Bandung.

Sommerfeld, Ray M., 1993, An Introduction To Taxation, Harcourt Brace Javanovich.

Sutarto, Eddhi, 2010, Rekonstruksi Sistem Hukum Pabean Indonesia, Penerbit Erlangga, Jakarta.

The New Encylopedia Britannica, 1988, Taxation, Encylopaedia Britannica Inc., London.

\section{B. Artikel Koran}

S., Andrea, "Pertumbuhan Meleset dari Target", Harian Kompas, 21 Februari 2014.

\section{Artikel Internet}

Anonim, Artikel "Pemerintah Persilakan Newmont dan Freeport Menggugat", www.bbc.co.uk/ indonesia, diakses 25 Februari 2013.

\section{Peraturan Perundang-Undangan}

Undang-Undang Nomor 28 Tahun 1999 tentang Penyelenggaraan Negara yang Bersih dan Bebas dari Korupsi, Kolusi, dan Nepotisme (Lembaran Negara Republik Indonesia Tahun 1999 Nomor 75, Tambahan Lembaran Negara Republik Indonesia Nomor 3851).

Undang-Undang Nomor 19 Tahun 2000 tentang Perubahan Atas Undang-Undang Nomor 19 Tahun 1997 tentang Penagihan Pajak dengan Surat Paksa (Lembaran Negara Republik Indonesia Tahun 2000 Nomor 129, Tambahan Lembaran Negara Republik Indonesia Nomor 3897).
Undang-Undang Nomor 17 Tahun 2006 tentang Perubahan Atas Undang-Undang Nomor 10 Tahun 1995 tentang Kepabean (Lembaran Negara Republik Indonesia Tahun 2006 Nomor 93, Tambahan Lembaran Negara Republik Indonesia Nomor 4661).

Undang-Undang No.4 Tahun 2009 tentang Pertambangan Mineral dan Batubara (Lembaran Negara Tahun 2009 Nomor 4, Tambahan Lembaran Negara Republik Indonesia Nomor 4959).

Undang-Undang Nomor 12 Tahun 2011 tentang Pembentukan Peraturan Perundang-undangan (Lembaran Negara Republik Indonesia Tahun 2011 Nomor 82, Tambahan Lembaran Negara Republik Indonesia Nomor 5234).

Peraturan Pemerintah Nomor 23 Tahun 2010 tentang Pelaksanaan Kegiatan Usaha Pertambangan Mineral dan Batubara (Lembaran Negara Republik Indonesia Tahun 2010 Nomor 29, Tambahan Lembaran Negara Republik Indonesia Nomor 5111).

Peraturan Pemerintah Nomor 55 Tahun 2008 tentang Pengenaan Bea Keluar Terhadap Barang Ekspor (Lembaran Negara Republik Indonesia Tahun 2008 Nomor 1116, Tambahan Lembaran Negara Republik Indonesia Nomor 4886).

TAP MPR Nomor IX/MPR/2001 Tentang Pembaruan Agraria Dan Pengelolaan Sumberdaya Alam.

Permen ESDM Nomor 1 Tahun 2014 tentang Peningkatan Nilai Tambah Mineral Melalui Kegiatan Pengolahan dan Pemurnian Mineral di Dalam Negeri.

PMK Nomor 75 Tahun 2012 tentang Penetapan Barang Ekspor Yang Dikenakan Bea Keluar Dan Tarif Bea Keluar.

PMK No. 153/ PMK.011/2014 Tahun 2014 tentang Perubahan Ketiga Atas Peraturan Menteri Keuangan No. 75/PMK.011/2012 tentang Penetapan Barang Ekspor yang Dikenakan Bea Keluar dan Tarif Bea Keluar. 


\section{E. Putusan Pengadilan}

Putusan MK No. 001-021-022/PUU-I/2003 tentang Permohonan Judicial Review UU No.20/ 2003 tentang Ketenagalistrikan.

\section{Lain-Lain}

Kontrak Karya PT. Newmont Nusa Tenggara dengan Pemerintah.

Wawancara dengan Djaka Kusmartata, narasumber dari Badan Kebijakan Fiskal Repulik Indonesia, pada 3 Juni Tahun 2014. 